\title{
端座位体幹回旋運動角度に対する 骨盤肢位と上肢肢位の影響
}

\author{
Effects of Pelvic Tilt and Upper Limb Position on Trunk Rotation Range \\ in Upright Sitting
}

\author{
松田 雅弘 ${ }^{1)}$ 田上 未来 ${ }^{1)} \quad$ 楠本 泰士 ${ }^{2)} \quad$ 滝田 結奈 ${ }^{3)} \quad$ 新田 收 ${ }^{4)}$ \\ TADAMITSU MATSUDA, RPT, $\mathrm{PhD}^{1)}$, MIKI TAGAMI, RPT, $\mathrm{PhD}^{1)}$, YASUAKI KUSUMOTO, RPT, $\mathrm{PhD}^{2)}$, \\ YUINA TAKITA, RPT ${ }^{3)}$, OSAMU NITTA, RPT, $\mathrm{PhD}^{4)}$ \\ ${ }^{1)}$ Faculty of Health Sciences, Uekusa Gakuen University: 1639-3 Ogura-cho, Wakaba-ku, Chiba-shi, Chiba 264-0007, Japan \\ TEL+81 43-239-2593 E-mail: t-matsuda@uekusa.ac.jp \\ 2) Faculty of Health Sciences, Tokyo University of Technology \\ ${ }^{3)}$ Department of Rehabilitation, Oyumino Central Hospital \\ 4) Graduate School of Human Health Sciences, Tokyo Metropolitan University
}

Rigakuryoho Kagaku 32(2): 255-259, 2017. Submitted Sep. 29, 2016. Accepted Nov. 18, 2016.

\begin{abstract}
Purpose] To investigate the effects of pelvic tilt and upper limb position on trunk rotation range in upright sitting. [Subjects and Methods] The trunk muscle activities and passive range of motion (ROM) of 20 healthy university students were measured. Under two conditions of pelvic tilt and upper limb position, the laterality of trunk rotation during upright sitting was measured. The differences among the conditions were divided into left and right and analyzed using two-way ANOVA, and the relationship of trunk rotational ROM with muscle strength was analyzed using Pearson correlation coefficients. [Results] Irrespective of the upper limb position, significant differences were found in the trunk rotation range with change in pelvic tilt; however, no significant changes were found between the upper limb positions. Furthermore, in the correct sitting posture, significant correlations were found between trunk rotational range and trunk range of motion and muscle strength. [Conclusion] The results suggest that changes in pelvic position affect the rotational range of the trunk, and in a correct sitting posture they correlates with trunk muscle strength.
\end{abstract}

Key words: trunk laterality, trunk rotation, pelvic tilt

要旨：〔目的〕端座位における骨盤肢位と上肢肢位の違いが体幹回旋運動の角度に及ぼす影響について検討した。〔対 象と方法】対象を健常大学生 20 名として，他動的体幹関節可動域，体幹筋力を計測した． 2 種類の骨盤肢位と上肢 肢位の端座位で, 左右体幹回旋角度を計測した。各条件の違いを左右に分けて二元配置分散分析, 体幹回旋可動域と 体幹筋力との関係をPearsonの相関係数で分析した。〔結果〕上肢肢位にかかわらず骨盤肢位の違いにより体幹回旋 運動角度に有意差がみられたが，上肢肢位の違いによる有意差はなかった。また，修正座位における体幹回旋運動角 度と，体幹関節可動域および体幹筋力の間に有意な相関がみられた。〔結語〕骨盤肢位の違いが，体幹回旋運動角度 に影響を及ぼし，修正座位における体幹筋力に相関していることが示唆される。 キ一ワード：体幹回旋運動，上肢肢位，骨盤肢位

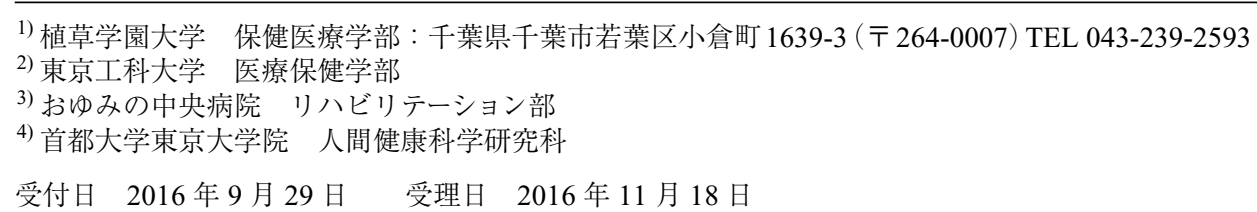




\section{I.はじめに}

体幹回旋運動は, 歩行動作に大きな影響 1)を与える ため, 座位バランス・歩行能力向上へつなげる運動療法 の 1 つの手段として, 体幹回旋運動を取り入れることが 多い, パーキンソン病では, 筋強剛や無動, 動作緩慢に よる運動量の減少や特有の体幹の前屈姿勢がみられ, 体 幹の関節可動域制限が生ずる 2)。脳卒中患者では, 体幹 アライメントに異常が生じ ${ }^{3)}$, 体幹筋活動との関連性 4,5$)$ が指摘されるとともに，それらは機能障害や能力低下に つながることが示唆されている，脳卒中患者における検 討で, 端座位の骨盤前傾群では後傾群と比較して, 有意 に立ち上がりおよび歩行能力が高く、したがって骨盤を 前傾させる能力が必要であるといえ, 実際に骨盤の傾斜 と日常生活活動との関連性が指摘されている6). また, 加齢に伴って骨盤後傾位になりやすく，それに伴い腰椎 が屈曲する7). 腰椎屈曲位では腰椎中間位と比較し, 体 幹回旋の可動性が低下するという報告 8 ももある。この ように加齢による春柱のアライメント变化や, 疾患に起 因した体幹回旋可動域の低下によって, これらが歩行動 作などの日常生活活動に影響を及ぼすため。これに対し て運動療法のなかに体幹回旋運動が取り入れられること が多い。

健常者に扮ける端座位の体幹回旋可動域の研究報告9) では，骨盤中間位の修正座位で体幹の左回旋のみに有意 な体幹回旋角度が増大して掞り，これは骨盤中間位では 脊柱の生理的彎曲が出現し, 脊柱全体の連動した回旋運 動が可能となり，その結果体幹回旋可動域が向上したと

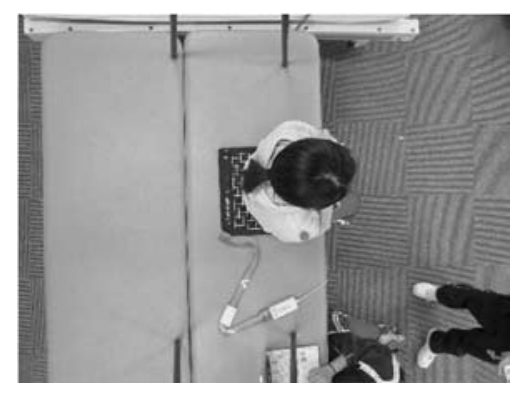

$\mathrm{a} ：$ 腕組み条件

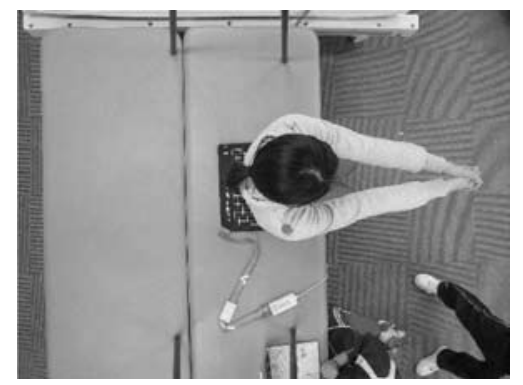

$\mathrm{b}$ ：腕伸展条件

図1 上肢肢位の条件別の座位姿勢
考えられている。しかし，体幹右回旋角度に有意差はみ られず，今後の検討が必要である．腰椎の肢位を変えて 体幹回旋可動域を比較した立位の報告 10) では, 腰椎の 可動性は中間位で最も大きく, 屈曲・伸展位では低下す るため, 腰椎の肢位により回旋可動域が影響を受けるこ とが示唆されている.このように, 腰椎・骨盤の肢位で 体幹回旋可動域が異なる.

端座位や立位に扔ける体幹の回旋は骨盤の動きを含む 複合的な動きであり，これに多くの要因が関連している ことが予測される，運動療法のなかでは，骨盤の肢位を 変えて体幹の回旋運動を促すだけではなく, 上肢肢位も 変化させて体幹の回旋運動を行う。しかし, 骨盤肢位や 上肢肢位の違いについては明らかになっていない，そこ で今回, 2 種類の骨盤肢位と 2 種類の上肢肢位が体幹回 旋運動の角度に及ぼす影響と, それらの要因分析として 体幹関節可動域挹よび体幹筋力を計測し, 体幹回旋運動 角度に及ぼす影響を分析することを目的とした。

\section{II. 対象と方法}

\section{1. 対象}

神経学的, 整形外科的な既往や問題のない健常大学生 20 名（男性 10 名, 女性 10 名), 年齢の平均（範囲） 20.2 歳 (19 20 歳), 身長の平均 \pm 標準偏差 $170.0 \pm 5.5$ $\mathrm{cm}$, 体重 $57.7 \pm 10.2 \mathrm{~kg}$ を対象とした。な㧍, 本研究 は全ての研究協力者に, ヘルシンキ宣言に基づき, 研究 の説明を行い，書面にて同意を得て実施した。

\section{2. 万法}

運動課題は対象者に端座位で随意的な最大体幹回旋運 動とし, そのときの体幹回旋の角度 (体幹回旋運動角度) を計測した。対象の両側肩峰にカラーマーカー 2 個を貼 付し, 運動開始前と体幹回旋最大運動時に, 対象の頭頂 上部に設置したデジタルカメラで撮像した，撮像した画 像は Image Jを利用して, ベッドの水平面と両側肩峰の マーカーを結んだ線との角度を体幹回旋運動角度とし, 左右それぞれで 2 回計測し，その平均值を採用した。体 幹回旋する順番はランダムとした。

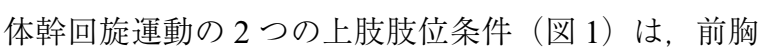
部で腕を組む（以下, 腕組み条件）と, 両肩関節 $90^{\circ}$ 屈 曲位・肘伸展位で手を組む（以下，腕伸展条件）とし, 各条件で左右に最大体幹回旋運動を 2 回実施した。骨盤 肢位の $2 つ の$ 条件は，座面に対して骨盤を起こした骨盤 中間位 (修正座位), 骨盤を最大後傾させた座位（骨盤 後傾座位）とした。 どの条件でも両膝関節 $90^{\circ}$ 屈曲位, 両足部を接地した端座位とし, 体幹回旋運動時に殿部と 足部が接地面から離れないように注意した。

関節可動域測定は, 日本整形外科学会の基準に則り, 1 名が固定し, 別の 1 名が計測した。 神中式ゴニオメー 
ターを用いて体幹屈曲・伸展，左右側屈・回旋可動域を 他動的に2 回計測し，平均值を採用した。体幹筋力は両 股関節・膝関節 $90^{\circ}$ 屈曲位した端座位で, 徒手筋力計 (Mobie，酒井医療社製）を用いて体幹屈曲・伸展，左 右側屈・回旋筋力を 2 回計測し，平均值を採用した。体 幹屈曲・伸展は伊藤 11) の推奨する方法に則り, 両上肢 を腕組み位とし, 徒手筋力計を Th7（両肩甲骨下角の高 さ）に設置して，壁固定法で体幹を伸展させ測定した。 体幹屈曲は徒手筋力計を胸骨頭に設置して, 圧迫法で体 幹を屈曲させ測定した。体幹回旋筋力は, 徒手筋力計を 回旋側肩峰に設置し, 体幹側屈筋力は, 徒手筋力計を側 屈側の肩峰から上腕骨の中間に設置して筋力を測定し た. 徒手筋力計が体幹回旋および側屈に対して垂直にな るように注意して, さらに，骨盤を測定補助者が固定し た状態で測定した。なお，各体幹筋力の 2 回の測定值の 平均を採用し, 各測定值の誤差が $10 \%$ 以上となる場合 は再度測定した。

統計処理は SPSS ver.21 を使用して，2つの骨盤肢位 を対応のある要因と, 2 つの上肢肢位を対応のある要因 で, 左右の体幹回旋運動角度を反復測定二元配置分散分 析後に, 単純主効果の検討を Sidak 法を用いて行い, す べて有意水準 5\%で行った。体幹関節可動域, 体幹筋力 と体幹回旋運動角度との関連性をPearsonの相関係数を 有意水準 5\%として検討した。

\section{III. 結 果}

2 種類の上肢肢位， 2 種類の骨盤肢位の違いに対する 体幹回旋運動角度の二元配置分散分析の結果, 各主効果 の検討を表 1 に示す。右体幹回旋運動角度では, 交互作 用を認めず，骨盤肢位の違いで主効果がみられ，事後検 定を行った結果, 両上肢肢位の条件とも骨盤肢位の違い で有意差がみられたが, 上肢肢位条件の違いで有意差は なかった。 また, 左体幹回旋運動では, 交互作用を認め ず，骨盤肢位の違いで主効果がみられ，事後検定を行っ た結果，腕伸展条件でのみ骨盤肢位の違いで有意差がみ

表 1 上肢肢位および骨盤肢位の違いと体幹回旋運動角度

\begin{tabular}{llc}
\hline & \multicolumn{2}{c}{ 体幹回旋運動角度 $\left({ }^{\circ}\right)$} \\
\cline { 2 - 3 } & \multicolumn{1}{c}{ 修正座位 } & 骨盤後傾座位 \\
\hline 右体幹回旋運動課題 & & \\
$\quad$ 腕組み条件 * & $63.2 \pm 11.5$ & $52.8 \pm 10.6$ \\
腕伸展条件 $*$ & $69.5 \pm 9.3$ & $58.7 \pm 13.0$ \\
左体幹回旋運動課題 & & \\
$\quad$ 腕組み条件 & $66.8 \pm 12.6$ & $55.2 \pm 14.1$ \\
腕伸展条件 $*$ & $70.2 \pm 9.9$ & $59.9 \pm 13.2$ \\
\hline
\end{tabular}

平均值 \pm 標準偏差. $*: \mathrm{p}<0.05$, 二元配置分散分析後, 主 効果を認めた場合に事後検定（Sidak 法）。
られたが，上肢肢位での違いで有意差はなかった（表 1).

体幹関節可動域および体幹筋力と体幹回旋運動角度の 間に有意な相関を認めた項目を表 2 に示す。骨盤後傾座 位と比較して, 左右体幹回旋運動とも修正座位の各項目 で有意な正の相関がみられた。修正座位における左右の 体幹回旋運動を比較すると, 右体幹回旋運動では, 両上 肢肢位の条件ともに体幹左側屈関節可動域に有意な正の 相関が, 腕組み条件でのみ体幹右側屈関節可動域におい ても有意な強い正の相関がみられた，左右体幹回旋運動 とも体幹筋力と相関がみられ，上肢肢位および骨盤肢位 すべての条件で，体幹屈曲筋力と中等度の正の相関がみ られた。その他, 体幹筋力は, 両上肢肢位ともに体幹屈 曲, 左右体幹側屈筋力との間に有意な中等度の正の相関 を，腕組み条件では左右体幹回旋筋力との間にも有意な 相関を示した。骨盤後傾座位における体幹回旋運動角度 は, 腕組み条件でのみ, 左体幹回旋筋力と体幹伸展筋力 の間にも有意な正の相関を示した。

\section{IV. 考 察}

体幹回旋運動角度は, 左体幹回旋運動角度の腕組み条 件以外で，骨盤後傾座位よりも修正座位で有意に増大し た（表 1)。骨盤傾斜角度の变化により矢状面における 春柱アライメントが変わると, 椎間関節の適合性や勒帯 の緊張が変化する ${ }^{12)}$. 骨盤後傾座位では腰椎の屈曲を 増強させる脊柱アライメントの変化が生じる7)。さらに, 腰椎屈曲位では腰椎中間位と比較し体幹回旋関節可動域 が低下するという報告 13) からも，骨盤と腰椎の連動し た変化によって体幹回旋運動角度に影響を及ぼしたこと が考えられる。また, 体幹の軸回旋の約 $80 \%$ は, 胸椎 で生じる 14) が, 腰椎が屈曲位になることで, 胸椎の後 弯が強まり胸郭の回旋可動域も小さくなり 13), 体幹の 回旋運動に影響を与えたと考えられる。今回の研究結果 でも，修正座位と比較して骨盤後傾座位では，体幹回旋 運動角度が低い值を示しており, 脊柱アライメントの変 化により骨盤後傾座位で低くなったと思われる.

次に, 上肢肢位の違いでは, 腕組み条件, 腕伸展条件 との間に体幹回旋運動角度の差がなかった（表 1 ）。腕 伸展条件で腕組み条件に比べて体幹回旋運動角度が大き い傾向にあり，腕伸展条件が両肩関節を屈曲し上肢を挙 上するため，体幹が伸展位になり，修正座位である骨盤 中間位, 胸椎伸展位に近づくことで体幹回旋運動角度が 増大したと考えられる。しかし, 上肢肢位の違いで体幹 回旋運動角度へ及ぼす影響は少なく, 今度さらに検討す る必要性がある。

さらに，修正座位では骨盤後傾座位よりも体幹関節可 動域および筋力との間に有意な相関を示した項目が多 かった（表 2)。体幹の回旋運動では，両側の背部筋と 
表 2 体幹関節可動域および体幹筋力と体幹回旋運動角度との相関関係が認められた項目

\begin{tabular}{lll}
\hline 上肢肢位 & \multicolumn{1}{c}{ 修正座位 } & 骨盤後傾座位 \\
\hline 右体幹回旋運動課題 & & \\
腕組み条件 & $\mathrm{R}$ 右側屈 $(\mathrm{r}=0.70), \mathrm{R}$ 左側屈 $(\mathrm{r}=0.71), \mathrm{M}$ 屈曲 & \\
& $(\mathrm{r}=0.56), \mathrm{M}$ 右回旋 $(\mathrm{r}=0.71), \mathrm{M}$ 左回旋 $(\mathrm{r}=0.60)$, & \\
& $\mathrm{M}$ 右側屈 $(\mathrm{r}=0.64), \mathrm{M}$ 左側屈 $(\mathrm{r}=0.51)$. \\
腕伸展条件 & $\mathrm{R}$ 左側屈 $(\mathrm{r}=0.54), \mathrm{M}$ 屈曲 $(\mathrm{r}=0.48), \mathrm{M}$ 右回旋 & \\
& $(\mathrm{r}=0.59), \mathrm{M}$ 左回旋 $(\mathrm{r}=0.48), \mathrm{M}$ 右側屈 $(\mathrm{r}=0.45)$. & \\
左体幹回旋運動課題 & & \\
腕組み条件 & $\mathrm{M}$ 屈曲 $(\mathrm{r}=0.52), \mathrm{M}$ 右回旋 $(\mathrm{r}=0.53), \mathrm{M}$ 左回旋 & $\mathrm{M}$ 伸展 $(\mathrm{r}=0.45)$ \\
& $(\mathrm{r}=0.48), \mathrm{M}$ 右側屈 $(\mathrm{r}=0.60), \mathrm{M}$ 左側屈 $(\mathrm{r}=0.49)$. & \\
腕伸展条件 & $\mathrm{M}$ 屈曲 $(\mathrm{r}=0.46), \mathrm{M}$ 右側屈 $(\mathrm{r}=0.55), \mathrm{M}$ 左側屈 & \\
& $(\mathrm{r}=0.48)$. & \\
\hline
\end{tabular}

$\mathrm{R}$ : 関節可動域, $\mathrm{M}$ : 筋力, $\mathrm{r}$ : Peason の相関係数, $\mathrm{p}<0.05$.

腹部筋が活動し，同側および反対側の体幹筋が協調的に 活動する ${ }^{15)}$ 。具体的には，背部筋の両側横突棘筋が収 縮し，腹部筋の同側内腹斜筋と反対側外腹斜筋が収縮す る.しかし, 骨盤後傾座位では大腰筋に加え, 春柱起立 筋や多裂筋などの体幹の抗重力筋の筋活動が不十分であ る可能性がある 5,16). 今回の研究結果からも, 体幹回旋 運動を円滑にするため, 修正座位では左右の腹部筋活動 に相関がみられたと考えられる。しかし，骨盤後傾座位 では，脊柱が屈曲位となるため腹部の筋は緩み，腹部筋 よりも背部の体幹伸筋が働き，腹筋群の収縮が低下する と考えられ，体幹筋活動との間に相関がみられなかった ものといえる.

すべての修正座位の条件で，体幹回旋運動角度と体幹 屈曲筋力が相関していることから, 体幹を最大に回旋さ せるには腹部の筋力が必要とされることが示唆される。 腹部笳は体幹の支持に重要な筋であり，体幹を回旋させ， 体幹を安定化させる機構にも働いたため, 体幹回旋運動 角度が大きいほど筋力を必要としたことが考えられる。 また，右体幹回旋運動では体幹の左右側屈の関節可動域 との間に相関はみられるが, 左体幹回旋運動では体幹筋 力との間にのみ相関がみられた（表 2). 特に腕組み条 件では, 修正座位すべてにおいて, 体幹回旋運動と両体 幹回旋筋力との間に相関がみられ，腕を組むことは，よ り強い体幹回旋筋力を発揮しなければ, 体幹を回旋させ られないことが考えられる。次に，上肢肢位の違いにか かわらず，修正座位では体幹回旋運動と体幹右側屈筋力, 体幹左側屈関節可動域との間に相関がみられた。体幹左 回旋では，立ち直りのため，体幹右回旋時では回旋方向 で体幹を支持するための壁としての機能として体幹筋が 活動したことが考えられる。体幹回旋運動角度は, 右体 幹回旋は左体幹回旋より可動性が低く, より可動性を増 大させるために体幹関節可動域との間に相関を示したと 考えられる。しかし，体幹の左回旋では同様の傾向が認
められなかったことから, 今後もさらなる検討が必要で ある。

今回，骨盤肢位と上肢肢位の違いによる体幹回旋運動 角度の違いについて検討した，端座位での体幹回旋運動 を促進させる運動において，骨盤肢位を考慮し体幹回旋 運動課題の設定を行っていく必要性がある。体幹の回旋 角度に及ぼす影響を検討したが，一定の傾向はみられず， 特にすべての条件で体幹の屈曲筋力が関与し, 腕組み条 件で体幹筋力との関連性が強く, 体幹筋力の向上を含め 運動療法を実施していくことを示唆する。健常者では, 身体の様々の部位において代償動作の発現が可能であり， 今後は高齢者や脳卒中患者で検討することで, 臨床的な 研究に発展できると考えられる.

\section{引用文献}

1) 横山茂樹, 松坂誠應, 大城昌平·他: 歩行時における肩甲帯. 骨盤帯の動き。理学療法ジャーナル, 1991, 25: 76-81.

2) 武澤信夫, 中川正法 : Unified Parkinson's disease rating scale と三次元動作解析を用いたパーキンソン病患者のリハ ビリテーションの有効性の検討. 日本リハビリテーション医 学, 2010, 47: 791-800.

3) Zakaria Y, Rashad U, Mohammed R: Assessment of malalignment of trunk and pelvis in stroke patients. Egypt $\mathrm{J}$ Neurol Psychiat Neurosurg, 2010, 47: 599-604.

4) Claus AP, Hides JA, Moseley GL, et al.: Different ways to balance the spine: Subtle changes in sagittal spinal curves affect regional muscle activity. Spine, 2009, 34: E208-E214.

5) O'Sullivan PB, Dankaerts W, Burnett AF, et al.: Effect of different upright sitting postures on spinal-pelvic curvature and trunk muscle activation in a pain-free population. Spine, 2006, 31: E707-E712.

6) 春山幸志郎, 川上途行：慢性期片麻瘏患者に扔ける端座位 での矢状面骨盤傾斜角度とその関連因子の検討。理学療法 学, 2015, 42: 50-57.

7) Levine D, Whittle MW: The effects of pelvic movement on 
lumbar lordosis in the standing position. J Orthop Sports Phys Ther, 1996, 24: 130-135.

8) Gunzburg R, Hutton W, Fraser R: Axial rotation of the lumbar spine and the effect of flexion: An in vitro and in vivo biomechanical study. Spine, 1991, 16: 22-28.

9) 椛山優太郎, 小牧隼人, 大久保鉄男 - 他 : 端座位姿勢の違 いによる体幹の自動回旋可動域の変化. 理学療法学, 2013, 40: 52 .

10) Montgomery T, Boocock M, Hing W: The effects of spinal posture and pelvic fixation on trunk rotation range of motion. Clin Biomech (Bristol, Avon), 2011, 26: 707-712.

11) 伊藤俊一：徒手筋力計による筋力評価プロジェクト. 理学 療法学, 2013, 40: 45.

12) Neumann DA: 筋骨格系のキネシオロジー，原著第 2 版。嶋
田智明・他 (監訳), 医歯薬出版, 東京, 2012, pp379-383.

13) 和田 治, 建内宏重, 市橋則明：骨盤の矢状面アライメン 卜が骨盤・体幹の回旋可動性扮よび身体重心移動に与える 影響. 理学療法学, 2009, 36: 356-362.

14) Fujii R, Sakaura H, Mukai Y, et al.: Kinematics of the lumbar spine in trunk rotation: in vivo three-dimensional analysis using magnetic resonance imaging. Eur Spine J, 2007, 16: 1867-1874.

15) 田中正一, 蜂須賀研二, 緒方 甫 : 脳卒中後片麻痺患者の 体幹回旋力. リハビリテーション医学, 1991, 31: 273.

16) Caneiro JP, O'Sullivan P, Burnett A, et al.: The influence of different sitting postures on head/neck posture and muscle activity. Man Ther, 2010, 15: 54-60. 